\title{
Nutritional status and production of noni plants fertilized with manure and potassium
}

\author{
Antônio Gustavo de Luna Souto ${ }^{1 *}$,Lourival Ferreira Cavalcante ${ }^{2}$, Maria Rosimere Miguel \\ da Silva ${ }^{3}$, Roberto Monteiro Ferreira Filho ${ }^{4}$, Antonio João de Lima Neto ${ }^{1}$, Belísia Lúcia \\ Moreira Toscano Diniz ${ }^{5}$
}

${ }^{1}$ Department of Plant Science, Federal University of Viçosa/UFV, Av. Peter Henry Rolfs s $/ n$, Campus Universitário, 36570-900, Viçosa, MG, Brazil. ${ }^{2}$ Researcher, National Institute of Science and Technology in Salinity - INCTSal. Department of Plant Science, Federal University of Paraiba/CCA/UFPB, Areia, PB, Brazil.

${ }^{3}$ Soil and Water Management, Federal University of Paraiba/CCA/UFPB, Areia, PB, Brazil. ${ }^{4}$ Department of Soil and Rural Engineering, Federal University of Paraiba/CCA/UFPB, Areia, PB, Brazil. ${ }^{5}$ Department of Agropecuária, Federal University of Paraíba/CCHSA/UFPB, Bananeiras, PB, Brazil.

*Corresponding author: antonio.souto@ufv.br

\begin{abstract}
Noni is a fruit species cultivated around the world, including Brazil however, scientific information about its nutritional status are scarce, thus justifying the need for more research on this topic to enhance its productive yield. This study aim is to evaluate both the mineral foliar composition and the productivity of noni plants cultivated in soil with cattle manure and potassium (K). The experiment was conducted from July 2012 to November 2013 at the Universidade Federal da Paraíba, Municipality of Bananeiras, Paraíba State. Treatments were organised according to a $5 \times 2$ factorial design involving five doses of $\mathrm{KCl}\left(0 ; 13.2 ; 37.5 ; 61.5\right.$; and $\left.69.6 \mathrm{~g} \mathrm{plant}^{-1}\right)$ in soil without cattle manure and with $4 \mathrm{~kg} \mathrm{plant}^{-1}$, in randomized blocks, with four repetitions and three plants per plot. The number of noni fruits harvested by plants fertilized with cattle manure increased from 51 to 70 fruits plant $^{-1}$. Compared to coffee trees, noni plants were adequately supplied with nitrogen, phosphorus, potassium, calcium, magnesium, sulphur, iron and zinc, but they were deficient in boron and manganese. The application of cattle manure to soil promoted contents of phosphorus and potassium in foliar samples, positively affecting the fruit formation and the production of noni plants.
\end{abstract}

Keywords: Morinda citrifolia L., fertilization, mineral composition, productivity. 


\section{Introduction}

Noni (Morinda citrifolia L.) is a fruit species of the Rubiaceae family that fructifies all year round during its productive stage in its whole productive branch (Cavalcante et al., 2014; Kuma and Ponnuswami, 2014). This species was domesticated and cultivated by the Polynesians in several regions of Tahiti and later, by different Hawaiian tribes; currently it is cultivated in the South Pacific, India, Caribbean and South America, including Brazil (Singh and Rai, 2007; Silva et al., 2014a; Souto et al., 2016).

Among the existing noni cultivars, M. citrifolia cv. citrifolia is the most important from a commercial point of view (Assi et al., 2015). The importance of the species is due to its chemical composition, such as its antibacterial, antiviral, antifungal and anti-inflammatory properties, as well as its associations with cancer prevention and increased immune response. These attributes have attracted the interests of specialized industries to process noni fruits for use in the production of drugs, insecticides and natural reagents (Singh and Rai, 2007; Assi et al., 2015).

In Brazil, noni was introduced at the beginning of the twenty-first century in São Luís city, located in Maranhão State. Scientific information regarding soil fertility and the nutritional needs of the noni plant is not widely available in the literature in Brazil or worldwide (Teixeira et al., 2016). Due to this lack of information, noni nutritional requirements are estimated using coffee trees (Coffea arabica) as a reference, given that both belong to the same family (Cavalcante et al., 2014; Silva et al., 2014a). Therefore, the establishment of adequate levels of nutrients is necessary to assist fertilization and nutritional requirement for noni cultivation plans (Silva et al., 2014a; Souto et al., 2016).

Potassium is one of the most exploited nutrients in noni cultures (Silva et al., 2014a) and is, in quantitative terms, the second most abundant in foliar tissues and the most present in fruits (Cavalcante et al., 2014). The importance of potassium (K) for plant species is due to several metabolic processes that it participates in such as; carbohydrate transport protein and enzyme activation, stomatal opening and closure, and photosynthesis (Marschner, 2012; Wang and $\mathrm{Wu}, 2013)$. In addition, this nutrient influences the absorption of other nutrients by plants, contributing to the improvement of the production quality (Moinuddin and Imas, 2010; Ranade-Malvi, 2011; Almeida et al., 2015; Anjos et al., 2015).

Noni cultures positively respond to the application of organic matter to the soil in the form of cattle manure, resulting in nutritionally balanced plants and fruits with adequate post-harvest quality (Kuma and Ponnuswami, 2014; Silva et al., 2014a; Souto et al., 2016). Despite the low concentration of nutrients in cattle manure, it holds all those essential to plants, and, after soil application, these are gradually released during the mineralization process, with lower losses compared to mineral fertilization (Higashikawa et al., 2010; Quilty and Cattle, 2011; Shah et al., 2016). Application of manure reduces production costs and provides quality production of fruits, as verified with mineral fertilization (Pacheco et al., 2017).

In addition, the application of organic material in the form of bovine manure associated with potassium mineral addition has contributed to the improvement of plant nutrition, with effects on production and quality of fruits (Rodrigues et al., 2009; Silva et al., 2014a; Souto et al., 2016). Considering the lack of information regarding the nutritional requirements of noni and its relation to production components, we aimed to evaluate the foliar mineral composition and production of noni plants fertilized with cattle manure and potassium. 


\section{Material and Methods}

\subsection{Characterization of the experimental area}

The study was carried out from July 2012 to November 2013 at the Center for Human, Social and Agrarian Sciences of the Universidade Federal da Paraíba, Municipality of Bananeiras, Paraíba State, Brazil. The municipality is georeferenced by the coordinates $6^{\circ} 46^{\prime} \mathrm{S}$ latitude and $35^{\circ} 38^{\prime} \mathrm{W}$ longitude from the
Greenwich Meridian, at $552 \mathrm{~m}$ of altitude.

The rainy season in this region is concentrated between April and August, with a drought from September to December. Throughout the experiment, the accumulated precipitation was $1,242 \mathrm{~mm}$, with the lack of rainfall during October and November of 2012 and maximum precipitation rates in June and July (Figure 1). For temperature and humidity, the average values were $25{ }^{\circ} \mathrm{C}$ and $65 \%$, respectively.

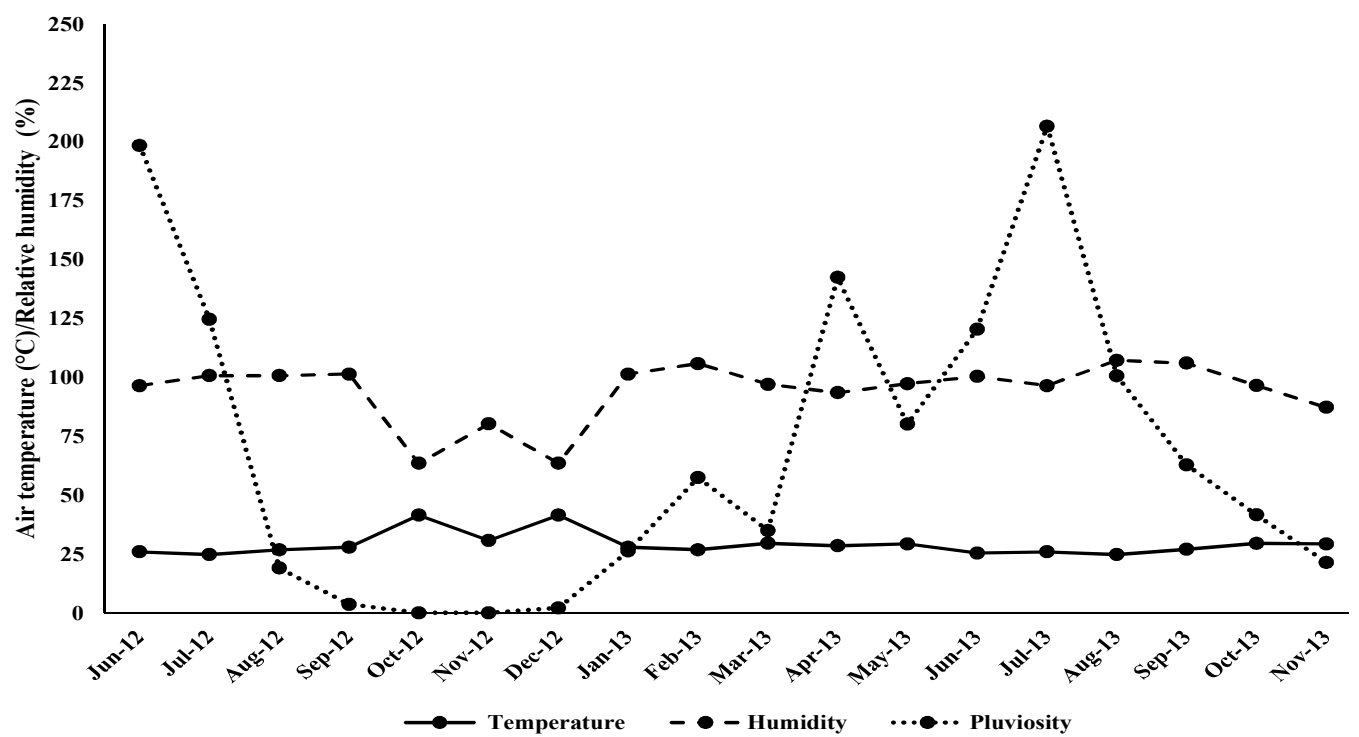

Figure 1. Mean monthly values of relative humidity (-), air temperature (‥) and pluviosity (- - -) throughout the experiment.

The soil of the experimental area was classified as dystrophic yellow latosol (Embrapa, 2013). Prior to the experiments, four soil samples per block were collected from the $0-40-\mathrm{cm}$ layer, totalling 12 samples. After drying in the shade, samples were sieved (2-mm mesh), transformed into composite samples and characterized by their physical and chemical attributes regarding fertility (Table 1 ), as described in Donagema et al. (2011). 
Table 1. Chemical and physical attributes of soil before the experiments in the $0-40$-cm layer.

\begin{tabular}{|c|c|c|c|}
\hline \multicolumn{2}{|c|}{ Chemical Attributes } & \multicolumn{2}{|c|}{ Physical Attributes } \\
\hline $\mathrm{pH} \mathrm{H} \mathrm{H}_{2} \mathrm{O}(1: 2,5)$ & 5.23 & Sand $\left(\mathrm{g} \mathrm{kg}^{-1}\right)$ & 653 \\
\hline $\mathrm{P}\left(\mathrm{mg} \mathrm{kg}^{-1}\right)$ & 0.33 & Silt $\left(\mathrm{g} \mathrm{kg}^{-1}\right)$ & 229 \\
\hline $\mathrm{K}^{+}\left(\mathrm{cmol}_{\mathrm{c}} \mathrm{kg}^{-1}\right)$ & 0.05 & Clay $\left(\mathrm{g} \mathrm{kg}^{-1}\right)$ & 118 \\
\hline $\mathrm{Ca}^{2+}\left(\mathrm{cmol}_{\mathrm{c}} \mathrm{kg}^{-1}\right)$ & 1.80 & $\mathrm{CDW}\left(\mathrm{g} \mathrm{kg}^{-1}\right)$ & 24.8 \\
\hline $\mathrm{Mg}^{2+}\left(\mathrm{cmol}_{\mathrm{c}} \mathrm{kg}^{-1}\right)$ & 1.16 & Soil Density $\left(\mathrm{g} \mathrm{cm}^{-3}\right)$ & 1.29 \\
\hline $\mathrm{Na}^{+}\left(\mathrm{cmol}_{\mathrm{c}} \mathrm{kg}^{-1}\right)$ & 0.01 & Particles Density $\left(\mathrm{g} \mathrm{cm}^{-3}\right)$ & 2.71 \\
\hline $\mathrm{SB}\left(\mathrm{cmol}_{\mathrm{c}} \mathrm{kg}^{-1}\right)$ & 3.01 & Flocculation Degree (\%) & 78.9 \\
\hline $\mathrm{Al}^{3+}+\mathrm{H}^{+}\left(\mathrm{cmol}_{\mathrm{c}} \mathrm{kg}^{-1}\right)$ & 4.58 & Dispersion Index (\%) & 21.1 \\
\hline $\mathrm{Al}^{3+}\left(\mathrm{cmol}_{\mathrm{c}} \mathrm{kg}^{-1}\right)$ & 0.46 & Total Porosity (\%) & 52.4 \\
\hline $\mathrm{CEC}\left(\mathrm{cmol}_{\mathrm{c}} \mathrm{kg}^{-1}\right)$ & 7.59 & Macroporosity (\%) & 40.1 \\
\hline $\mathrm{V}(\%)$ & 39.7 & Microporosity (\%) & 12.3 \\
\hline $\mathrm{N}(\%)$ & 0.09 & $\mathrm{U}_{\mathrm{cc}}-0.01 \mathrm{MPa}(\%)$ & 12.3 \\
\hline $\mathrm{OC}(\%)$ & 0.98 & $\mathrm{U}_{\mathrm{pmp}}-1.50 \mathrm{MPa}(\%)$ & 3.8 \\
\hline $\operatorname{MOS}(\%)$ & 1.69 & Available Water (\%) & 8.5 \\
\hline $\mathrm{EC}\left(\mathrm{mS} \mathrm{cm}^{-1}\right)$ & 0.05 & Textural Classification: & Franc Sandy \\
\hline
\end{tabular}

$\mathrm{CDW}=$ clay dispersed in water; $\mathrm{pH}=$ hydrogen ionic potential; $\mathrm{P}=$ phosphorus, Mehlich-1; $\mathrm{K}^{+}=$potassium, Mehlich-1; $\mathrm{Na}^{+}$ = sodium, $\mathrm{KCl} 1 \mathrm{~mol} / \mathrm{L} ; \mathrm{Ca}^{2+}$ = calcium, $\mathrm{KCl} 1 \mathrm{~mol} / \mathrm{L} ; \mathrm{Mg}^{2+}$ = magnesium, $\mathrm{KCl} 1 \mathrm{~mol} / \mathrm{L} ; \mathrm{SB}=$ sum of exchangeable bases $\left(\mathrm{Ca}^{2+}+\mathrm{Mg}^{2+}+\mathrm{K}^{+}\right) ; \mathrm{H}^{+}+\mathrm{Al}^{3+}=$ potential acidity, $\mathrm{Ca}$ acetate $0.5 \mathrm{~mol} / \mathrm{L}, \mathrm{pH} 7.0 ; \mathrm{Al}^{3+}=$ exchangeable aluminium, Ca acetate 0.5 $\mathrm{mol} / \mathrm{L}, \mathrm{pH} 7.0 ; \mathrm{CEC}=$ cation exchangeable capacity $\left[\mathrm{SB}+\left(\mathrm{H}^{+}+\mathrm{Al}^{3+}\right) ; \mathrm{V}=\right.$ percentage of saturation by exchangeable bases $[\mathrm{V}=$ $(\mathrm{SB} / \mathrm{CTC}) 100] ; \mathrm{N}=$ nitrogen; $\mathrm{OC}=$ organic carbon, Walkley-Black method; MOS = organic matter of the soil, Walkley-Black method; $\mathrm{EC}=$ electrical conductivity of the aqueous extract $(1: 2.5)$.

\subsection{Soil and plant management in the experimental} area

Prior to treatment, the experimental area was limed with $3.3 \mathrm{t} \mathrm{ha}^{-1}$ of calcitic lime $(47 \% \mathrm{CaO}, 2 \% \mathrm{MgO}$ and $81 \%$ of PRNT), applied on the entire surface and incorporated at a depth of $0-20 \mathrm{~cm}$ to increase the soil's saturation percentage using exchangeable bases from 39.7 to $80.0 \%$ (Cavalcanti, 2008). Sixty days after liming, pits were opened $(40 \times 40 \times 40 \mathrm{~cm})$ with a distance of $4 \mathrm{~m}$ between plants and lines, followed by seedling transplantation.
Fertilization processes were performed as suggested by Silva et al. (2014a). Phosphorus (P) was divided into three applications of $40 \mathrm{~g}_{\text {plant }}{ }^{-1}$ of $\mathrm{P}_{2} \mathrm{O}_{5}$. The first was performed after pit preparation, the second was made 30 days after transplantation (DAT) and the third was performed 270 DAT using simple superphosphate ( $18 \%$ of $\mathrm{P}_{2} \mathrm{O}_{5}, 16 \%$ of $\mathrm{Ca}, 12 \%$ of $\mathrm{S}$ ). Nitrogen $(\mathrm{N})$ was divided into three doses of $30 \mathrm{~g}$ plant $^{-1}$ at 30, 270 and 330 DAT (08/2012;04/2013 and $06 / 2013$ ), deriving from ammonium sulfate $(20 \% \mathrm{~N})$. 


\subsection{Experimental design and treatments}

All seedlings were derived from seeds and were transplanted to the field at 90 DAT, with an average of four pairs of completely expanded leaves. Treatments were distributed according to a $5 \times 2$ factorial design in randomized blocks with four replicates and three plants per plot. The factors were five doses of potassiumchloride $\left(0 ; 13.2 ; 37.5 ; 61.5\right.$; and 69.6 g plant $\left.^{-1}\right)$ to in- crease $\mathrm{K}$ levels in the soil from 20 to $45 ; 90 ; 135$ and $150 \mathrm{mg} \mathrm{dm}^{-3}$ in the soil with and without application of $12 \mathrm{~kg}$ of cattle manure, at a carbon-to-nitrogen ratio $(\mathrm{C} / \mathrm{N})$ of $18: 1$ to increase the organic matter index from $1.69 \%$ (initial rate) to $4.00 \%$, taking into account the soil volume of the pit. Before its application, samples of cattle manure were collected and chemically analysed for fertility (Table 2), as suggested by Donagema et al. (2011).

Table 2. Chemical characterization of the cattle manure used in the experiment.

\begin{tabular}{|c|c|c|c|c|c|c|c|}
\hline & \multicolumn{7}{|c|}{ Chemical Characterization } \\
\hline \multicolumn{8}{|c|}{ Macronutrients } \\
\hline \multirow{2}{*}{$\begin{array}{c}\mathrm{pH}\left(\mathrm{H}_{2} \mathrm{O}\right) \\
(1: 2,5)\end{array}$} & $\mathrm{N}$ & $\mathrm{P}$ & $\mathrm{S}$ & $\mathrm{K}^{+}$ & $\mathrm{Ca}^{2+}$ & $\mathrm{Mg}^{2+}$ & $\mathrm{C}: \mathrm{N}$ \\
\hline & ----g dm-3---- & \multicolumn{2}{|c|}{---mg dm ${ }^{3}---$} & \multicolumn{3}{|c|}{ 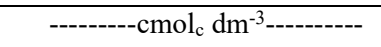 } & \\
\hline \multirow[t]{4}{*}{8,58} & $187.85 \quad 10.44$ & 2.07 & 6.65 & 2.49 & 4.65 & 5.25 & $18: 1$ \\
\hline & \multicolumn{7}{|c|}{ Micronutrients } \\
\hline & $\mathrm{Na}^{+}$ & $\mathrm{B}$ & & $\mathrm{Cu}$ & $\mathrm{Fe}$ & $\mathrm{Mn}$ & $\mathrm{Zn}$ \\
\hline & 130.9 & 0.84 & & 1.38 & 21.77 & 44.18 & 4.13 \\
\hline
\end{tabular}

$\mathrm{pH}=$ hydrogen ionic potential; $\mathrm{C}=$ carbon, oxidated by potassium dichromate and determined by colorimetry; $\mathrm{N}=$ nitrogen, N-Kjeldahl by wet digestion; $\mathrm{P}=$ phosphorus, Mehlich 1 and photocolorimeter reading, $660 \mathrm{~nm}$; $\mathrm{S}=$ sulphur, spectrophotometry with wavelength readings of $420 \mathrm{~nm} ; \mathrm{K}^{+}=$potassium and $\mathrm{Na}^{2+}=$ sodium, determined by flame photometer; Ca $\mathrm{Ca}^{2+}=$ calcium and $\mathrm{Mg}^{2+}$ magnesium, determined by atomic absorption spectrophotometer at wavelengths of 422.7 and $285.2 \mathrm{~nm}$, respectively; C:N $=$ carbon/nitrogen ratio; $\mathrm{B}=$ boron and $\mathrm{Fe}=$ iron, determined by UV-VIS spectrophotometer at wavelengths of 460 and $508 \mathrm{~nm}$, respectively; $\mathrm{Cu}=$ copper, determined by atomic absorption spectrophotometer at a wavelength of $324.7 \mathrm{~nm} ;$; Mn $=$ manganese and $\mathrm{Zn}=$ zinc, determined by EAA with flame air-acetylene.

Both potassium chloride and cattle manure were divided into 3 equal plots of $0 ; 4.4 ; 12.5 ; 20.5$ and 23.2 g plant ${ }^{-1}$ of $\mathrm{KCl}$ and $4 \mathrm{~kg}$ plant $^{-1}$ of cattle manure dried in shade with 5\% humidity, discounting the existing water in the organic input humidity. The first fertilization with both fertilizers was performed in the foundation during pit preparation (07/01/2012), while the second and third fertilizations were performed in the hedge at $30 \mathrm{DAT}(08 / 01 / 2012)$ and 270 DAT $(03 / 01 / 2013)$. 


\subsection{Nutritional parameters evaluated}

Leaf samples were collected from the third and fourth pairs of leaves at 510 DAT (11/2013), which corresponded to the period when the plants were in full bloom, as described by Kumar and Ponnuswami (2014) and Silva et al. (2014a) for noni plants cultivated in India and Brazil, respectively. Counting from the top to bottom of the branches located in the median part of the plants and in each quadrant of the treetop, 12 leaves were collected (Malavolta et al., 1997). This is the methodology adopted for foliar sample collection from coffee trees. Samples were dried in an air-circulating oven at $65^{\circ} \mathrm{C}$ for 72 $\mathrm{h}$, then milled and placed in paper bags appropriately identified with the treatment, date of collection, species, organ and researcher responsible for the material. Samples were then sent to the laboratory for determination of macro (N, P, K, Ca, Mg, S) and micronutrient (B, Fe, Mn and $\mathrm{Zn}$ ) levels by means of the methods proposed by Bataglia et al. (1983).

\subsection{Productive parameters evaluated}

Fruit harvest was conducted on a weekly basis from 330 to 510 DAT, when the fruits showed the same colour as the whitened bark, which is considered the picking point for noni fruit (Silva et al., 2014b). All fruits were counted to calculate the number of $f$ ruits
(NF) harvested per plant, and fruits were weighed with a semi-analytical (model L3102 Mettler-Toledo Ind. and Com. Ltda., Barueri, São Paulo State, Brazil) weighting scale to calculate production per plant (PP).

\subsection{Statistical analysis}

Data were obtained in four replicates and submitted to a variance analysis by the $\mathrm{F}$ test $(p<0.05$ and $p<0.01)$. The mean values in reference to variation factor cattle manure were compared by the $\mathrm{F}$ test at $5 \%$ and $1 \%$ probability \pm standard variation (SD), which is conclusive for two values of the same factor, while the values referring to the doses of potassium chloride were compared by regression analysis with the software SISVAR 5.6 (Ferreira, 2014).

\section{Results}

\subsection{Plant nutrition}

The interaction between potassium and cattle manure had a significant effect on the foliar contents of nitrogen, sulphur (S), manganese (Mn) and zinc ( $\mathrm{Zn})$ (Table 3). Phosphorus and potassium rates responded to the isolated effects of $\mathrm{KCl}$ and cattle manure, but foliar levels of calcium $(\mathrm{Ca})$, magnesium $(\mathrm{Mg})$, boron (B) and iron ( $\mathrm{Fe}$ ) were not different facing any variation source, as well as its interaction. 
Table 3. Summary of variance analysis based on the mean square for foliar contents of macronutrients $(N, P, K, C a$, $\mathrm{Mg}$ and $\mathrm{S}$ ) and micronutrients (B, Fe, Mn and $\mathrm{Zn}$ ) in noni plants fertilized with potassium chloride and cattle manure.

\begin{tabular}{|c|c|c|c|c|c|c|c|}
\hline \multirow{2}{*}{ SV } & \multirow{2}{*}{ DF } & \multicolumn{6}{|c|}{ Mean Square } \\
\hline & & $\mathrm{N}$ & $\mathrm{P}$ & $\mathrm{K}$ & $\mathrm{Ca}$ & $\mathrm{Mg}$ & $\mathrm{S}$ \\
\hline Blocks & 2 & $0.40^{\mathrm{ns}}$ & $0.03^{\text {ns }}$ & $8.13^{\text {ns }}$ & $1.63^{\mathrm{ns}}$ & $0.03^{\text {ns }}$ & $0.03^{\mathrm{ns}}$ \\
\hline Potassium (K) & 4 & $4.95^{\mathrm{ns}}$ & $0.71^{*}$ & $32.21 *$ & $7.08^{\mathrm{ns}}$ & $0.20^{\mathrm{ns}}$ & $0.33^{* *}$ \\
\hline Cattle manure (M) & 1 & $4.03^{\mathrm{ns}}$ & $4.03 * *$ & $300.83^{* *}$ & $0.30^{\mathrm{ns}}$ & $0.03^{\mathrm{ns}}$ & $3.33 * *$ \\
\hline $\mathrm{K} \times \mathrm{M}$ & 4 & $19.45^{* *}$ & $0.28^{\mathrm{ns}}$ & $9.91^{\mathrm{ns}}$ & $0.71^{\mathrm{ns}}$ & $0.20^{\mathrm{ns}}$ & $0.33 * *$ \\
\hline Residue & 18 & 1.95 & 0.18 & 7.20 & 3.63 & 0.18 & 0.33 \\
\hline Total & 29 & -- & -- & -- & -- & -- & -- \\
\hline Mean & & 6.95 & 17.51 & 14.31 & 18.83 & 2.96 & 3.33 \\
\hline CV (\%) & & 20.30 & 2.43 & 18.76 & 13.78 & 14.36 & 5.48 \\
\hline \multirow{2}{*}{ SV } & \multirow{2}{*}{$\mathrm{DF}$} & \multicolumn{6}{|c|}{ Mean Square } \\
\hline & & B & & & $\mathrm{Mn}$ & & $\mathrm{Zn}$ \\
\hline Blocks & 2 & $18.43^{\text {ns }}$ & 111 & $10^{\mathrm{ns}}$ & $12.40^{\mathrm{ns}}$ & & $6.03^{\mathrm{ns}}$ \\
\hline Potassium (K) & 4 & $14.63^{\mathrm{ns}}$ & 454 & & $164.38 * *$ & & $40.80 * *$ \\
\hline Cattle manure (M) & 1 & $1.63^{\mathrm{ns}}$ & 140 & & $145.20 * *$ & & $34.13 * *$ \\
\hline $\mathrm{K} \times \mathrm{M}$ & 4 & $21.96^{\mathrm{ns}}$ & 121 & $83^{\text {ns }}$ & $76.61^{* *}$ & & $38.46^{* *}$ \\
\hline Residue & 18 & 9.58 & & & 12.17 & & 3.58 \\
\hline Total & 29 & -- & & & -- & & -- \\
\hline Mean & & 32.43 & & & 32.40 & & 14.26 \\
\hline CV (\%) & & 9.54 & & & 10.70 & & 13.28 \\
\hline
\end{tabular}

Regarding the treatments without cattle manure, doses up to $32.2 \mathrm{~g}$ of $\mathrm{KCl}$ stimulated an increase of $\mathrm{N}$ content in noni leaves, reaching a maximum estimated value of $25.62 \mathrm{~g} \mathrm{~kg}^{-1}$, while other doses decreased the $\mathrm{N}$ content of plants (Figure 2A). The foliar contents of $\mathrm{N}$ in noni plants raised with cattle manure did not correspond to increased $\mathrm{KCl}$ in any of the regression models, exhibiting a mean value of $19.20 \mathrm{~g}$ $\mathrm{kg}^{-1}$. Foliar P contents increased from 1.97 to $2.87 \mathrm{~g}$ $\mathrm{kg}^{-1}$ between plants grown in soil without and with the maximum estimated $\mathrm{KCl}$ dose of $35.7 \mathrm{~g} \mathrm{plant}^{-1}$, providing an increase of $45.68 \%$ (Figure $2 \mathrm{~B}$ ). The foliar $\mathrm{P}$ contents were increased from 2.05 to $2.73 \mathrm{~g} \mathrm{~kg}^{-1}$ between plants raised in soil without and with cattle manure (Figure 2C).

The foliar contents of $\mathrm{K}$ were linearly increased at a rate of $0.0713 \mathrm{~g} \mathrm{~kg}^{-1}$ by the unitary increase of potassic fertilization applied to the soil (Figure 2D) in amounts ranging from 16.18 to $21.15 \mathrm{~g} \mathrm{~kg}^{-1}$. This increase yielded a difference of $30.7 \%$ between treatments with and without the dose of $69.6 \mathrm{~g}$ plant $^{-1}$ of $\mathrm{KCl}$. Similar to the results for $\mathrm{P}$, the foliar content of $\mathrm{K}$ increased from 16.65 to $21.61 \mathrm{~g} \mathrm{~kg}^{-1}$ with the application of cattle manure, representing a difference of $29.8 \%$ between plants in soil without and with this input (Figure 2E). 

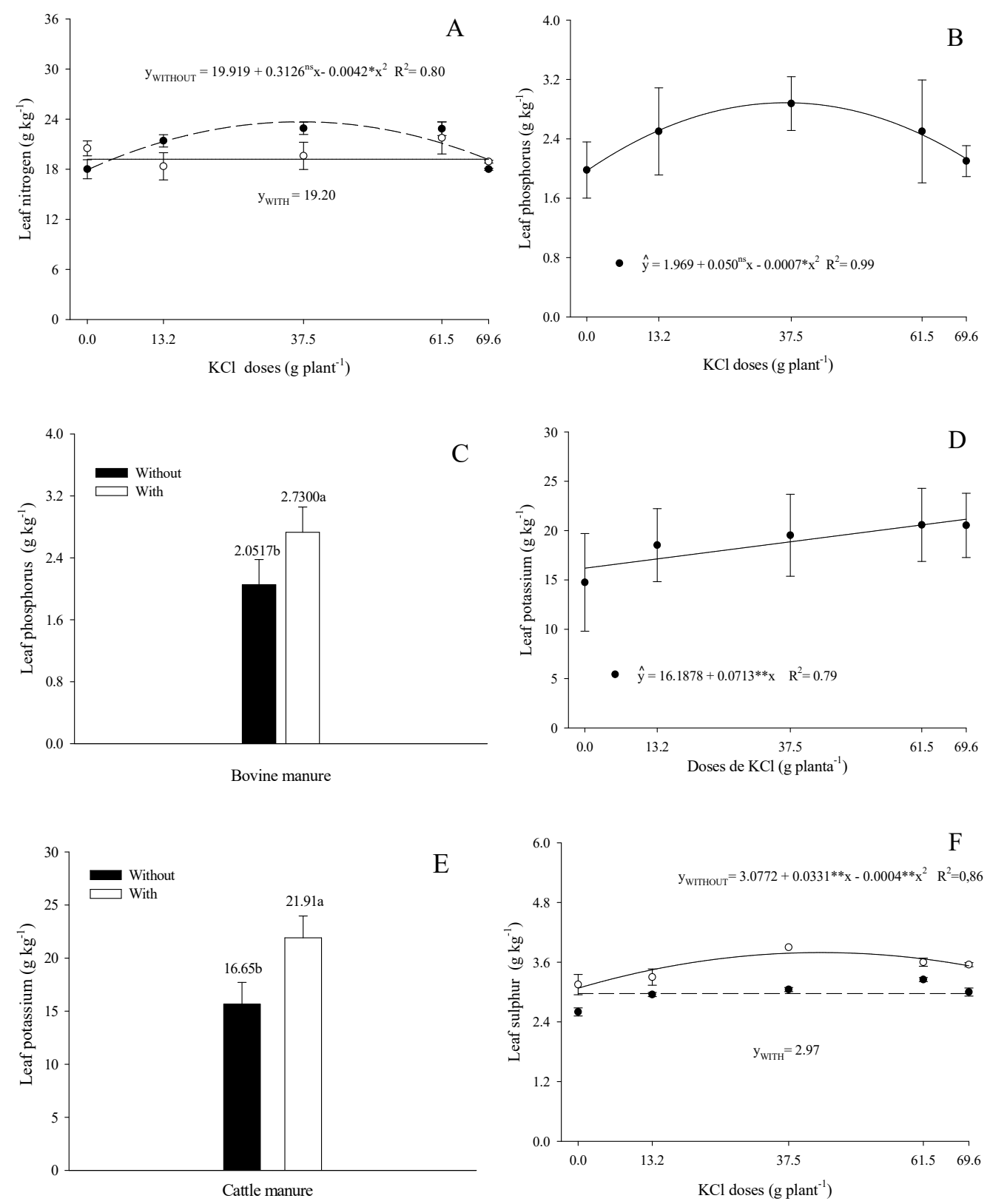

Figure 2. Leaf nitrogen (A) and sulphur (F) for noni leaves grown in soil without (- - -) and with (-) the corresponding doses of potassium chloride; leaf phosphorus (B) and potassium (D) in noni leaves of plants grown in soil with doses of potassium chloride; leaf phosphorus (C) and potassium (E) in noni leaves of plants raised in soil without and with cattle manure. 
Levels of $\mathrm{Ca}^{2+}$ and $\mathrm{Mg}^{2+}$ in leaf dry matter did not exhibit treatment effects; however, their average values were 18.83 and $2.96 \mathrm{~g} \mathrm{~kg}^{-1}$, respectively. In both situations, noni plants were nutritionally balanced in sulphur compared to coffee tree demands (Malavolta et al., 1997). The foliar contents of S did not vary according to $\mathrm{KCl}$ dose in the soil without cattle manure; the average value of $\mathrm{S}$ was $2.97 \mathrm{~g} \mathrm{~kg}^{-1}$. At the same condition of potassic fertilization, $\mathrm{S}$ levels for plants fertilized with an organic fertilizer increased to a maximum value of $3.76 \mathrm{~g} \mathrm{~kg}^{-1}$ with the maximum estimated $\mathrm{KCl}$ dose of $41.4 \mathrm{~g} \mathrm{plant}^{-1}$.

Boron and iron leaf levels were not influenced by any of the experimental manipulations, with average values of 32.43 and $182.90 \mathrm{mg} \mathrm{kg}^{-1}$ (Table 3), respectively. These nutrients show that noni plants, when compared to coffee trees during the sampled period, were deficient in B, but adequately supplied with $\mathrm{Fe}$ (Farnezi et al., 2009).

The foliar content of manganese in plants raised without cattle manure was elevated by an estimated
$\mathrm{KCl}$ dose of $52 \mathrm{~g} \mathrm{plant}^{-1}$, reaching a maximum value of $35.45 \mathrm{mg} \mathrm{kg}^{-1}$ (Figure 3A). Similarly, $\mathrm{KCl}$ doses of up to $35.5 \mathrm{~g} \mathrm{plant}^{-1}$ in soil containing cattle manure increased the foliar content of $\mathrm{Mn}$ to a maximum of $43.1 \mathrm{mg} \mathrm{kg}^{-1}$ (Figure 3B). By comparing the highest foliar contents of Mn for treatments without and with manure, we found that organic input increased the foliar manganese content of noni plants by 21.6 percent. The foliar contents of zinc in treatments without cattle manure linearly increased by $0.0481 \mathrm{mg} \mathrm{kg}^{-1}$ with unitary increments of $\mathrm{KCl}$ dose (Figure 3C). Values rose from 11.4 to $14.7 \mathrm{mg} \mathrm{kg}^{-1}$ between plants in soil without and with the highest $\mathrm{KCl}$ dose, thus indicating a $29 \%$ increase under the same conditions. Such $\mathrm{KCl}$ increases in the treatment without manure stimulated the foliar contents of $\mathrm{Zn}$ to the highest dose of 34.8 g plant $^{-1}$ of the mineral fertilizer, enabling a $\mathrm{Zn}$ value of $21.3 \mathrm{mg} \mathrm{kg}^{-1}$; this difference represented a $92.06 \%$ gain relative to plants raised in soil without $\mathrm{KCl}$.
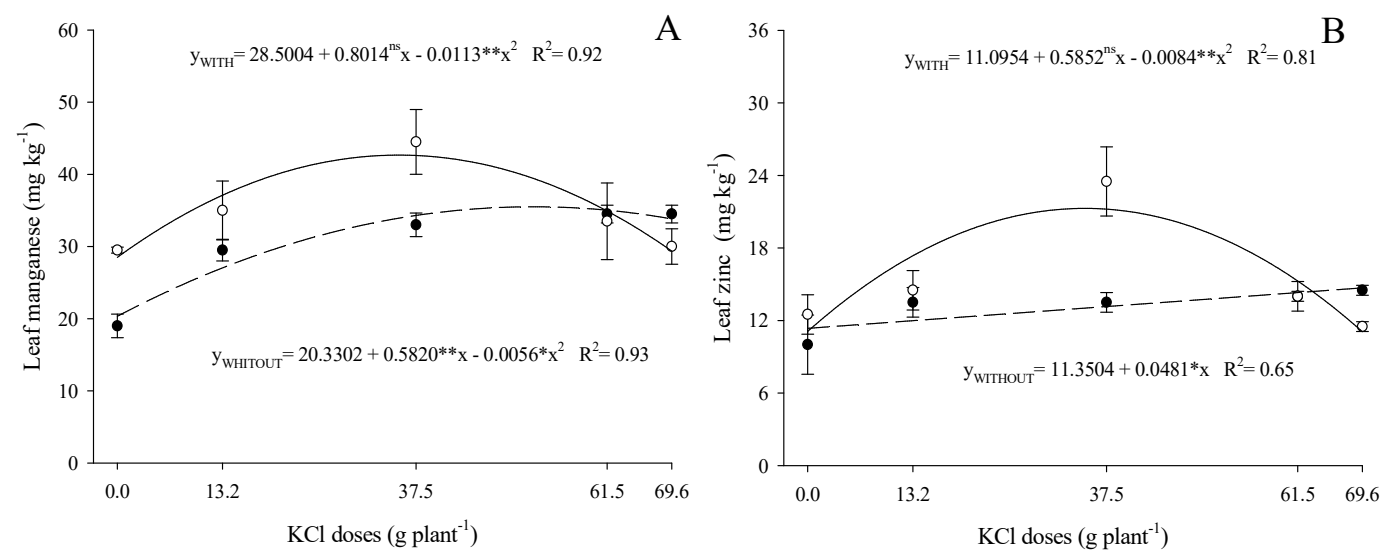

Figure 3. Leaf manganese and zinc in noni plants as a function of different doses of potassium chloride in soil without (- - ) and with (-) cattle manure. 


\subsection{Production}

The number of fruits and plants produced did not vary according to theinteraction of potassium doses with cattle manure; however, it was influenced both by mineral and organic fertilization (Table 4).

Table 4. Summary of variance analysis, based on the mean square for fruit number and production by noni plants as a function of potassium chloride and cattle manure content in soil.

\begin{tabular}{cccc}
\hline SV & NF & \multicolumn{2}{c}{ Mean Square } \\
\cline { 3 - 4 } & & Number of Fruits & Production \\
\hline Blocks & 3 & $21.63^{\text {ns }}$ & $3.42^{\text {ns }}$ \\
Potassium (K) & 4 & $155.15^{* *}$ & $29.08^{* *}$ \\
Cattle manure (M) & 1 & $3,534.40^{* *}$ & $93.02^{* *}$ \\
K $\times$ M & 4 & $29.40^{\text {ns }}$ & $3.08^{\text {ns }}$ \\
Residue & 27 & 22.94 & 1.18 \\
Total & 39 & -- & -- \\
\hline Mean & & 60.65 & 6.52 \\
\hline CV $(\%)$ & & 7.94 & 16.68 \\
\hline
\end{tabular}

The addition of cattle manure and potassium stimulated increases in fruits per plant relative to soil without the respective fertilizers (Figure 4). The number of fruits harvested from plants fertilized with manure increased from 51 to 70 fruits plant ${ }^{-1}$, representing an increase of 19 fruits plant $^{-1}$ or $37 \%$ relative to treatments without manure (Figure 4A). Increasing doses of $\mathrm{KCl}$ have linearly raised the number of noni fruits from 53 to 65 fruits plant ${ }^{-1}$, representing a $22.6 \%$ increment between plants in soil without and with the highest applied dose (69.6 g plant $^{-1}$ ) of potassium chloride (Figure 4B).
As observed for the number of fruits, cattle manure and potassium chloride enhanced plant production. The range of 5.11 to $7.99 \mathrm{~kg}$ plant $^{-1}$ represents an increase of $56.4 \%$ in plant mass compared to plants grown in soil without cattle manure (Figure 4C). Moreover, potassium chloride stimulated fruit production relative to plants grown in soil without the mineral input, with values of 4.89 and $8.95 \mathrm{~kg} \mathrm{plant}^{-1}$, representing an increase of $83 \%$ between treatments without and with the highest dose of $\mathrm{KCl}$ (Figure 4D). 

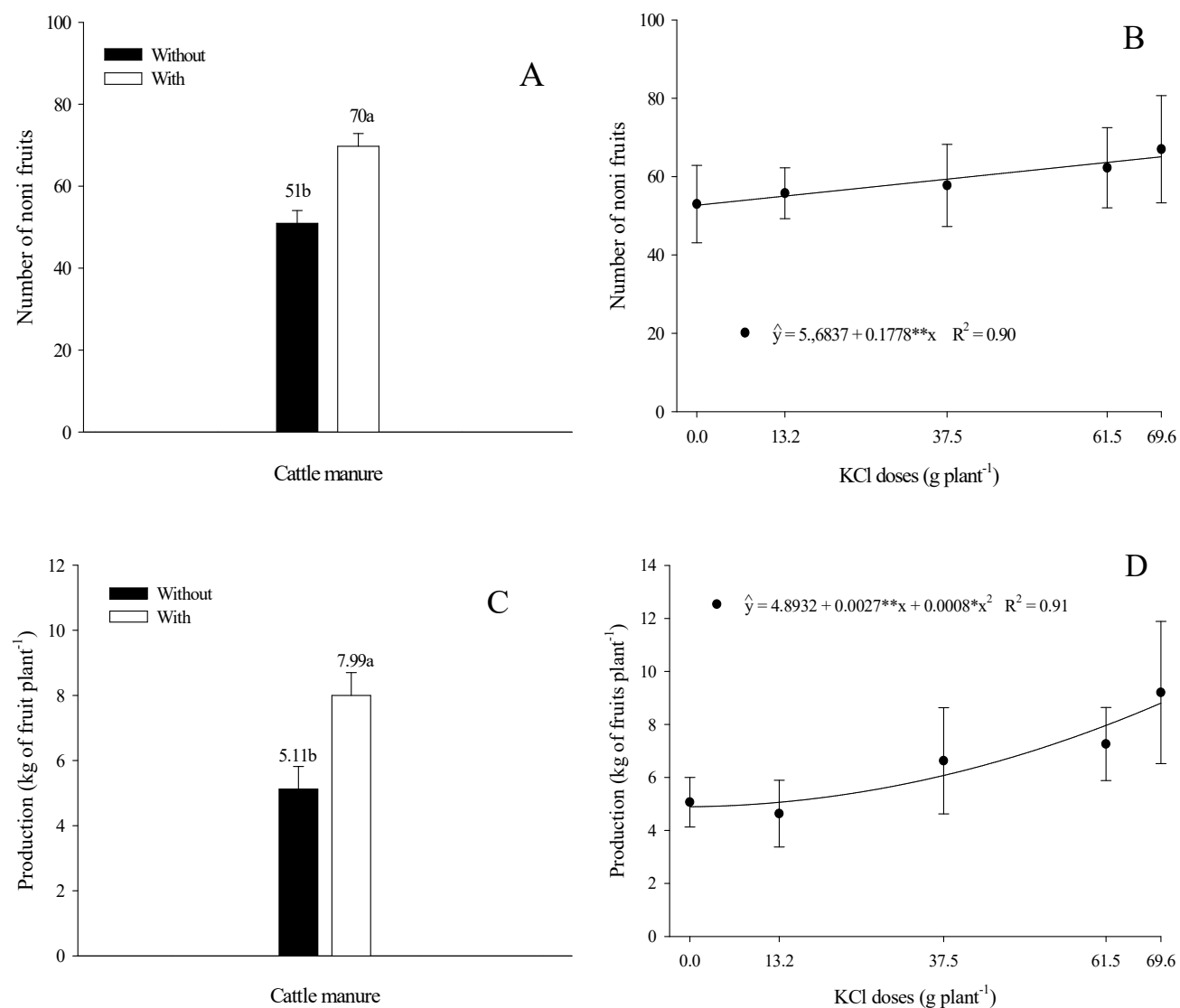

Figure 4. Number of noni fruits and production for plants raised in soil without and with cattle manure (A) and doses of potassium chloride (B).

\section{Discussion}

The statistical results for calcium and magnesium data (Table 3) are in accordance with Silva et al. (2014a), as they concluded that both the interaction between potassium and cattle manure and the treatment effects had significant effects on content of the respective macronutrients in noni leaves at 33 months of age and nine months after the treatment application. The aforementioned authors observed that only the foliar contents of $\mathrm{K}, \mathrm{B}, \mathrm{Fe}, \mathrm{Mn}$ and $\mathrm{Zn}$ in noni plants were influenced by the interaction between potassium fertilization and cattle manure.
The results for leaf nitrogen (Figure 2A) indicate that only plants fertilized with $\mathrm{KCl}$ had adequate content, which varied from 22.5 to $27.9 \mathrm{~g} \mathrm{~kg}^{-1}$ in the Brazilian coffee cultures (Farnezi et al., 2009). A foliar N content of $25.62 \mathrm{~g} \mathrm{~kg}^{-1}$ in plants treated with $32.2 \mathrm{~g} \mathrm{plant}^{-1}$ of $\mathrm{KCl}$ was observed, which exceeded the value of $19.14 \mathrm{~g} \mathrm{~kg}^{-1}$ as reported by Kumar and Ponnuswami (2014) for the same culture and phenological period (blooming and fructification) fertilized with cattle manure under irrigation in India. However, the results do not exceed the value $35 \mathrm{~g} \mathrm{~kg}^{-1}$ of foliar $\mathrm{N}$ reported by Silva et al. (2014a) in plants of the same culture, fertilized with cattle manure. 
Such increases are due to the use of organic matter (cattle manure), which accelerates the mineralization rate of $\mathrm{P}$ in soil, thus contributing to the production of organic acids that occupy the phosphate adsorption site in the soil, increasing phosphate availability to plants (Pavinato and Rosolem, 2008; Thangarajan et al., 2013). Similar results were obtained by Kumar and Ponnuswami (2014) and Silva et al. (2014a), who noted that the application of cattle manure increased P content by $47.7 \%$ and $28.0 \%$ in India and Brazil, respectively.

Increased $\mathrm{KCl}$ in the soil stimulates both the absorption and transfer of $\mathrm{K}$ from plants to leaves (Figure 4B) and, according to Ranade-Malvi (2011) and Marschner (2012), contributes to increased metabolic activity of $\mathrm{N}$, given that protein synthesis is also dependent on adequate potassic nutrition. Under such conditions, elevated $\mathrm{K}$ content in leaves activates nitrate reductase (an enzyme that catalyses proteins) in foliar tissues. Similar behaviour was observed by Anjos et al. (2015) in papaya cv. "Tainung no 1 " (Carica papaya L.) and by Ferreira Neto et al. (2014) in coconut trees (Cocos nucifera) cultivated in Brazil. These researchers verified that increasing doses of a potassic fertilizer stimulated the increase of $\mathrm{N}$ foliar content in the respective fruit trees.

Such increases result from the fact that the fertilizer is a source of potassium, and the growing data are consistent with increased potassic fertilization in banana Musa ssp cv. "Pacovan Apodi” (Barroso et al., 2011), guava - Psidium guajava cv. "Paluma" (Amorim et al., 2015), papaya cv. "Tainung $\mathrm{n}^{\mathrm{o}} 1$ " (Anjos et al., 2015) and sugarcane - Saccharum robustum (Almeida et al., 2015), all cultivated in Brazil.

Cattle manure is an excellent nutrient source (Table 2 ), and after its mineralization, this nutrient is released into the soil, thus incrementing its absorption by plants and elevating its contents in leaves. Organic fertilizers release nutrients in a balanced and gradual way, thus contributing to nutrient losses reduction, especially by lixiviation, and enhancing soil fertility, as in the case of potassium (Quilty and Cattle, 2011; Kumar and Ponnuswami, 2014). The lowest level of potassium, which ranged from 16.18 to $21.61 \mathrm{~g} \mathrm{~kg}^{-1}$ exceeded the value of $12 \mathrm{~g} \mathrm{~kg}^{-1}$ observed by Singh and Rai (2007) in the foliar tissue of noni plants cultivated in India, as well as the range between 13.6 and 14.6 $\mathrm{g} \mathrm{kg}^{-1}$ observed by Silva et al. (2014a) in noni plants cultivated in Brazil. These results verify the importance of potassic fertilization for noni mineral nutrition, given that potassium is the second most abundant element in leaves and the most present in fruits (Cavalcante et al., 2014).

Considering that noni's demands for calcium and magnesium are similar to those of coffee trees, plants were adequately supplied both in calcium and in magnesium (Farnezi et al., 2009). Increases in the foliar contents of $\mathrm{S}$ in plants fertilized with cattle manure are explained by the organic input, which is a source of this element (Table 2), as well as by the $12 \%$ of $\mathrm{S}$ originating from the simple superphosphate; it is seen that when both are applied simultaneously, sulphur availability in plants increases (Higashikawa et al, 2010). Regardless of the benefits provided by cattle manure compared to treatments with only the simple superphosphate, the foliar contents of $\mathrm{S}$ were below the level of $8.9 \mathrm{~g} \mathrm{~kg}^{-1}$, as observed by Silva et al. (2014a) in plants of the same species fertilized with cattle manure and potassium, indicating that noni is a demanding culture with respect to sulphur.

The increase of leaf manganese is in accordance with the report of Ranade-Malvi (2011), who reported a synergistic effect between $\mathrm{K}$ and $\mathrm{Mn}$, in which the nutrient's increase contributed to a greater absorption of $\mathrm{K}$. Our results are also in accordance with Amorim et al. (2015), who observed a linear increase in foliar Mn content in guava plants that received potassic fertilization from 0.0 to $2.2 \mathrm{~kg} \mathrm{plant}^{-1}$ for three consecutive 
cycles. Despite the increase of Mn content with the application of organomineral fertilization, these values are below the ranges of 1.576 to $2.329 \mathrm{mg} \mathrm{kg}^{-1}$ (Silva et al., 2014a) and 1.075 to $1.888 \mathrm{mg} \mathrm{kg}^{-1}$ (Teixeira et al., 2016) obtained in the same culture and below the range of 80 to $100 \mathrm{mg} \mathrm{kg}^{-1}$, which is considered sufficient for coffee cultivation (Malavolta et al., 1997).

Results for leaf zinc were similar to those observed by Moinuddin and Imas (2010) by applying $\mathrm{K}_{2} \mathrm{O}$ doses from 0 to $60 \mathrm{~kg} \mathrm{ha}^{-1}$ and supported a linear increase in $\mathrm{Zn}$ leaf content in sorghum plants (Sorghum bicolor). The results of Rodrigues et al. (2009) for yellow passion fruit plants cultivated in Brazil and treated with different doses of bovine biofertilizer in soil containing $\mathrm{KCl}$ were similar to the current results for noni plants fertilized with doses of potassium and cattle manure.

Comparatively, the foliar content of $\mathrm{Zn}$ was below the range of 99.0 to $111.7 \mathrm{mg} \mathrm{kg}^{-1}$ obtained by Silva et al. (2014a) and 140.4 to $200.9 \mathrm{mg} \mathrm{kg}^{-1}$ by Teixeira et al. (2016) for noni plants cultivated in Brazil. In contrast to coffee trees, Malavolta et al. (1997) suggested that adequate levels of $\mathrm{Zn}$ were between 15 to $20 \mathrm{mg} \mathrm{kg}^{-1}$. This finding indicates that noni plants differ from coffee trees in their nutritional demands and highlights the importance of defining adequate levels in this culture.

Similar results to those reported in Table 4 were obtained by Souto et al. (2016), who also observed an absence of significant effects for the interaction of noni fruit mass and length. A similar tendency to that illustrated in Figure 4A was verified by Pacheco et al. (2017) for passion fruit plants in Brazil: this study observed that the application of cattle manure in soil increased the number of fruits per plant, exceeding the yield of plants treated with only mineral fertilizers.

Similar results to those reported in Figure 4B were presented by Anjos et al. (2015) who observed that by applying $\mathrm{KCl}$ in the soil, the number of fruits per plant was elevated. Such increases reflect a response to $\mathrm{K}$ availability to plants due to fertilization with $\mathrm{KCl}$, as indicated by the foliar contents (Figure 4B). According to Wang and $\mathrm{Wu}$ (2013), potassium participates in metabolic reactions as a protein and enzyme activator; and in stomatal conductance with roles in carbohydrate transport, respiration and photosynthetic rates in plants, thus positively affecting production of crops such as noni. The yield of fruits per plant, regardless of cattle manure or potassium content in the soil (Figure 4C and 4D), is associated both with an increased number of fruits harvested (Figure 4A and $4 \mathrm{~B}$ ) and greater average mass of fruits, as observed by Souto et al. (2016) for plants of the same species given different treatments.

\section{Conclusions}

Noni plants respond to fertilization with cattle manure and $\mathrm{KCl}$, reflecting increases in the number of fruits and in production per plant. Compared to coffee trees, noni plants were adequately supplied with $\mathrm{N}, \mathrm{P}, \mathrm{K}, \mathrm{Ca}$, $\mathrm{Mg}, \mathrm{S}, \mathrm{Fe}$ and $\mathrm{Zn}$ and deficient in B and Mn. The application of cattle manure improves the foliar contents of $\mathrm{P}$ and $\mathrm{K}$, positively affecting on the formation and production of fruits in noni plants.

\section{Acknowledgements}

The authors thank the National Council of Scientific and Technological Development (CNPq) and the Coordination for Higher Education Personal Development (CAPES) for their financial support of this project and the scholarship provided to the first author. 


\section{References}

Almeida, H.J., Pancelli, M.A., Prado, R.M., Cavalcante, V.S., Cruz, F.J. R. 2015. Effect of potassium on nutritional status and productivity of peanuts in succession with sugarcane. J. Soil Sci. Plant Nutr. 15, 1-10.

Amorim, D.A., Souza, H.A., Rozane, D.E., Montes, R.M., Natale, W. 2015. Adubação nitrogenada e potássica em goiabeiras 'Paluma': II. Efeito no estado nutricional das plantas. Rev. Bras. Frutic. 37, 210-219.

Anjos, D.C., Hernandez, F.F.F., Costa, J.M.C., Caballero, S.S.U., Moreira, V.O.G. 2015.Fertilidade do solo, crescimento e qualidade de frutos do mamoeiro Tainung sob fertirrigação com potássio. Rev. Ciên. Agron. 46, 774-785.

Assi, R.A., Darwis, Y., Abdulbaqi, I.M., Khan, A.A., Vuanghao, L., Laghari, M.H. 2015. Morindacitrifolia (Noni): A comprehensive review on its industrial uses, pharmacological activities, and clinical trials. Arab. J. Chem. 1-17.

Barroso, A.A.F., Viana, T.V.A., Marinho, A.B., Costa, S.C., Azevedo, B.M. 2011. Teores de macronutrientes em folhas de bananeira cv. Pacovan Apodi, sob lâminas de irrigação e doses de potássio. Eng. Agríc. 31, 529-538.

Bataglia, O.C., Furlani, A.M.C., Teixeira, J.P.F., Furlani, P.R., Gallo, J.R. 1983. Métodos de análise química de plantas. Campinas, Instituto Agronômico, 48p.

Cavalcante, L.F., Silva, J.J.M., Rocha, L.F., Dantas, T.A.G., Bezerra, F.T.C., Nascimento, J.A.M. 2014. Adubação, composição mineral, irrigação e produção do noni. In: Silva, J.J.M., Cavalcante, L.F. (eds). Noni: Breve conhecimento da planta e bases para a produção, Sal da Terra, João Pessoa, PB, pp: 45-70.
Cavalcanti, F.J.A. 2008. Recomendações de adubação para o Estado de Pernambuco: segunda aproximação. 3. ed. Recife, PE, Instituto Agronômico de Pernambuco, $212 \mathrm{p}$.

Donagema, G.K., Campos, D.V.B., Calderano, S.B., Texeira, W.G., Viana, J.H.M. 2011. Manual de métodos de análise de solo. 2. ed. Rio de Janeiro, RJ, Embrapa Solos, 230 p.

EMBRAPA. 2013. Empresa Brasileira de Pesquisa Agropecuária. Centro Nacional de Pesquisa de Solos. Sistema Brasileiro de Classificação de Solos. $3^{\circ}$ ed. Brasília, DF, Embrapa Solos, 353p.

Farnezi, M.M.M., Silva, E.B., Guimarães, P.T.G. 2009.Diagnose nutricional de cafeeiros da região do Alto Jequitinhonha (MG): normas DRIS e faixas críticas de nutrientes. Rev. Bras. Ciênc. Solo. 33, 969-978.

Ferreira, D.F. 2014. Sisvar: a guide for its bootstrap procedures in multiple comparisons. Ciênc. Agrotec. 8, 109-112.

Ferreira Neto, M., Holanda, J.S., Gheyi, H.R., Folegatti, M.V., Dias, N.S. 2014. Atributos químicos do solo e estado nutricional de coqueiro anãofertirrigado com nitrogênio e potássio. Rev. Caatinga, 27, 30-40.

Higashikawa, F.S., Silva, C.A., Bettiol, W. 2010. Chemical and physical properties of organic residues. Rev. Bras. Ciênc. Solo. 34, 1742-1752.

Kumar, S.M., Ponnuswami, V. 2014. Soil and leaf nutrient status of noni (Morinda citrifolia L.) as influenced by drip irrigation and manurial treatments. Afr. J. Agric. Res. 9, 376-386.

Malavolta, E., Vitti, G.C., Oliveira, S.A. 1997. Avaliação do estado nutricional das plantas: princípios e aplicações. 2 ed. Piracicaba, SP, Potafós, 319 p.

Marschner, H. 2012. Mineral nutrition of higher plants. Third .ed London, Elsevier, 643p. 
Menezes, E.F., Cavalcante, L.F., Mesquita, F.O., Campos, V.B., Dantas, T.A.G. 2012. Composição mineral do maracujazeiro amarelo em resposta ao biofertilizante bovino e cloreto de potássio no solo. Rev. Bras. Ciênc. Agra. 7, 260-268.

Moinuddin Imas, P. 2010. Effect of zinc nutrition on growth, yield, and quality of forage sorghum in respect with increasing potassium application rates. J. Plant Nutr. 33, 2062-2081.

Pacheco, A.L.V., Pagliarini, M.F., Freitas, G.B., Santos, R.H.S., Serrão, J.E., Zanucio, J.C. 2017. Mineral composition of pulp and production of the yellow passion fruit with organic and conventional fertilizers. Food Chem. 217, 425-430.

Pavinato, P.S., Rosolem, C.A. 2008. Disponibilidade de nutrientes no solo - decomposição e liberação de compostos orgânicos de resíduos vegetais. Rev. Bras. Ciênc. Solo. 32, 911-920.

Quilty, J.R., Cattle, S.R. 2011. Use and understanding of organic amendments in Australian agriculture: a review. Soil Res. 49, 1-26.

Radane-Malvi, U. 2011. Interaction of micronutrients with major nutrients with special reference to potassium. Karnataka J. Agric. Sci. 24, 106-109.

Rodrigues, A.C., Cavalcante, L.F., Oliveira, A.P., Sousa, J.T., Mesquita, F.O. 2009. Produção e nutrição mineral do maracujazeiro-amarelo em solo com biofertilizante supermagro e potássio. Rev. Bras. Eng. Agríc. Ambient. 13, 117-124.

Shah, G.M., Shah, G.A., Groot, J.C.J., Raza, M.A.S., Shahid, N., Lantinga, E.A. 2016. Maize nitrogen recovery and dry matter production as affected by application of solid cattle manure subjected to various storage conditions. J. Soil Sci. Plant Nutr. 16, 591-603.
Silva, J.J.M., Cavalcante, L.F., Diniz, B.L.M.T., Souto, A.G.L., Bezerra, M.A.F. 2014b. Colheita e pós-colheita do noni. In: Silva, J.J.M., Cavalcante, L.F. (eds). Noni: Breve conhecimento da planta e bases para a produção, Sal da Terra, João Pessoa, PB, pp: 99-110.

Silva, J.J.M., Cavalcante, L.F., Nascimento, J.A.M., Diniz, B.L.M.T., Souto, A.G.L. 2014a. Esterco bovino e potássio na composição mineral de plantas de noni. Ciênc. Florest. 24, 1021-1030.

Singh, D.R., Rai, R.B. 2007. Morindacitrifolialinn.ó an important fruit tree of andaman and nicobar islands. Nat. Prod. Rad. 6, 62-65.

Souto, A.G.L., Cavalcante, L.F., Fraga, V.S., Diniz, B.L.M.T., Silva, M.R.M., Ferreira Filho, R.M., Mesquita, E.F., Dantas, E.A.G., Sá, F.V.S. 2016. Physical and physicochemical attributes of noni fruits fertilized with cattle manure and potassium. Afr. J. Agric. Res. 11, 2720-2729.

Teixeira, R.A., Brandão, A.D.S., Souza, E.S., Fernandes, A.R., Amarante, C.B., Neves, P.A.P.F.G. 2016. Teores de flavonóides e nutrientes em plantas de noni cultivadas em solos com atributos químicos contrastantes. Rev. Cienc. Agrar. 59, 196-202.

Thangarajan, R., Bolan, N.S., Tian, G., Naidu, R., Kunhikrishnan, A. 2013. Role of organic amendment application on greenhouse gas emission from soil. Sci. Total Environ. 465, 72-96.

Wang, Y., Wu, W.H. 2013. Potassium transport and signaling in higher plants. Annu. Rev. Plant Biol. 64, 451-476. 